Vol. 11, No. 1, 2021

\title{
THE SPIN-POLARIZED ELECTRONIC AND MAGNETIC PROPERTIES OF ZINC SELENIDE HEAVY DOPED WITH CHROMIUM
}

\author{
Stepan Syrotyuk \\ Lviv Polytechnic National University, Lviv, Ukraine \\ stepan.v.syrotiuk@lpnu.ua
}

\begin{abstract}
At the first stage, the structure of the $\mathrm{ZnSe}$ crystal doped with chromium atoms $(\mathrm{ZnCrSe})$ has been found by optimization procedure. At the second stage, the electronic properties of this material have been evaluated within the two approaches. The exchangecorrelation functionals used here are based on the generalized gradient approximation (GGA) and the hybrid functional PBE0. The GGA approach provides the metallic state for electrons with the spin up, and for opposite spin orientation the material $\mathrm{ZnCrSe}$ bahaves as semiconductor, with the band gap of $2.48 \mathrm{eV}$. The hybrid functional approach also gives a gapless state for a spin up electron states, and for a spin down it provides the forbidden gap value of $2.39 \mathrm{eV}$. The magnetic moment of the unit cell, found with the two functionals, is the same and equals to $4 \mu_{B}$ (Bohr magnetons). So, the calculations with the two exchange-correlation functionals provide the prediction of half-metallic properties of the $\mathrm{ZnCrSe}$ material, which is an interesting candidate for spintronic applications.
\end{abstract}

Key words: doped semiconductor, half-metal, strong correlations, spintronics.

\section{Introduction}

Doping of semiconductors II-VI with transition metals aims to find materials that can be used in optoelectronics and spintronics. Recently, studies of crystal $\mathrm{ZnTe}$ doped with $\mathrm{Cr}$, Mn, and Ti atoms have been performed [1]. In a work [2] the optical properties of the material CdMnTe were studied, and a work [3] was devoted to the study of the influence of taking into account the strong correlations of $3 \mathrm{~d}$ electrons on the parameters of the electronic energy spectrum of this material.

\section{Calculation}

The calculations have been done within the projector augmented waves (PAW) approach [4]. This method reveals the features of the pseudopotential and the all-electron method of augmented plane waves. The all-electron $\psi_{n}$ function is derived from pseudo-wave $\mid \psi_{n}>$ one by means of transformation $\tau$, namely:

$$
\left|\psi_{n}(\mathbf{r})\right\rangle=\tau\left|\psi_{n}(\mathbf{r})\right\rangle
$$

where operator

$$
\tau=1+\sum_{a} \sum_{i}\left(\left|\phi_{i}^{a}\right\rangle-\left|\phi_{i}^{o j}\right\rangle\right)\left\langle\phi_{i}^{a}\right|
$$

is built on the atomic $\left|\phi_{i}^{a}(\mathbf{r})\right\rangle$, pseudoatomic $\mid \phi_{i}^{0}(a)(\mathbf{r})>$ and projector $\left\langle p_{i}^{a}\right|$ functions. The equations (1) and (2) define the basis states PAW. The energy band spectrum $\varepsilon_{n}$ of the crystal is evaluated from the following system of equations,

$$
\tau^{+} H \tau\left|\Psi_{n}\right\rangle=\tau^{+} \tau\left|\Psi_{n}\right\rangle \varepsilon_{n}
$$

where the spectra of the effective Hamiltonian $\tau^{+} H \tau$ and initial one $H$ are identical. The exchange-correlation energy functional was taken in the hybrid form [5], named as the PBE0.

$$
E_{x c}^{P B E 0}[\rho]=E_{x c}^{P B E}[\rho]+\alpha\left(E_{x}^{H F}\left[\Psi_{3 d}\right]-E_{x}^{P B E}\left[\rho_{3 d}\right]\right) .
$$

This form combines the usual PBE approach [6] and Hartree-Fock exchange energy (HF). The parameter $\alpha$ is a mixing coefficient. If $\alpha=0$, the PBE0 approximation becomes a usual functional of PBE. The recommended value of mixing parameter is $\alpha=0.25$ [5]. Both values of the $\alpha$ are used here. The hybrid functional PBE0 used with mixing parameter $\alpha \neq 0$ causes removing the self-interaction error (SIE), which is very important for transition metal compounds [3,7].

The supercell of the material is built on base of the sphalerite structure. The unit cell contains $3 \mathrm{Zn}$ atoms, $1 \mathrm{Cr}$ atom and $4 \mathrm{Se}$ atoms. The parameters of a unit cell were optimized by the Broyden-Fletcher-Goldfarb-Shanno [8] (BFGS) scheme of the searh of stable structure geometry.

The calculations have been done by means of the ABINIT code [9].

\section{Results and discussion}

The spin-polarized electronic energy bands, obtained without the SIE, are given in Fig. 1. The Fermi level defines the origin on the energy axis. As can be seen from Fig. 1 the Fermi level crosses the the dispesion curves in the upper part 
of the valence band. So, the electrons with the spin up move in a considered material as in a metal.

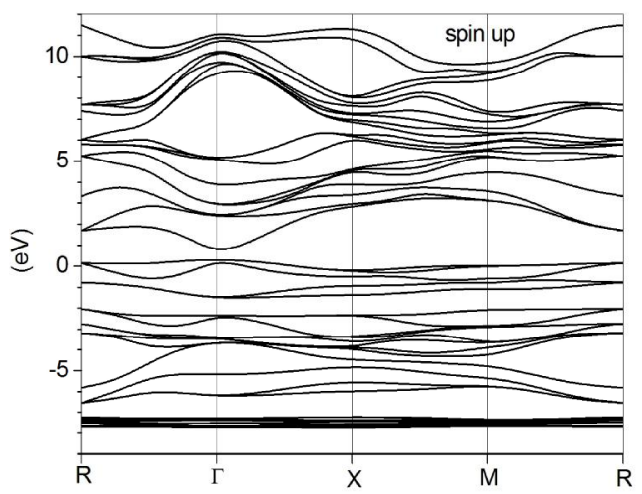

Fig. 1. The electronic energy bands in the $\mathrm{ZnCrSe}$ material obtained with a mixing parameter $\alpha=0$.

In contrast to this, the electrons with the spin down, as can be seen from Fig. 2, are characterized by semiconductor energy bands. Here the Fermi level is situated inside the forbidden gap and is slightly shifted towards the conduction band.

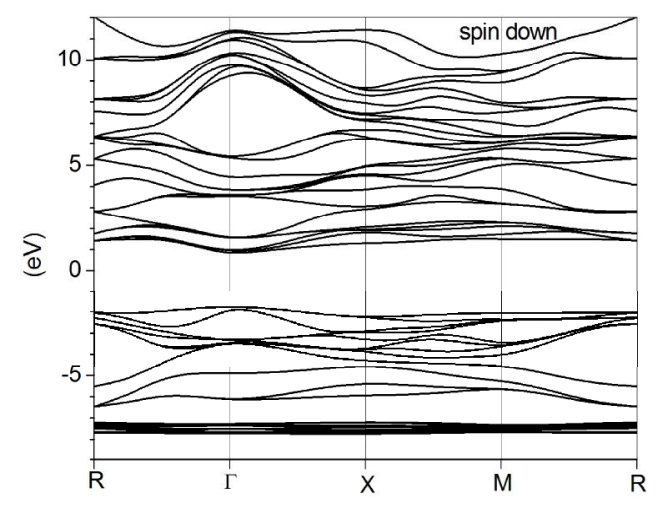

Fig. 2. The electronic energy bands in the $\mathrm{ZnCrSe}$ material obtained with a mixing parameter $\alpha=0$.

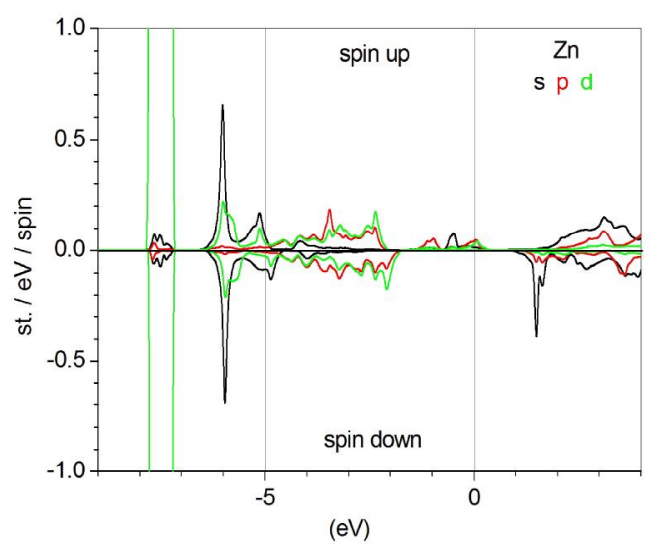

Fig. 3. The partial DOS of Zn in the material ZnCrSe evaluated with a mixing parameter $\alpha=0$.
The partial DOS in Fig. 3 are not symmetric for electrons with opposite spins. The asymmery is caused by strongly correlated $3 \mathrm{~d}$ electrons of $\mathrm{Cr}$ atom. The Fermi level crosses the $\mathrm{p}$ levels of the $\mathrm{Zn}$ atom.

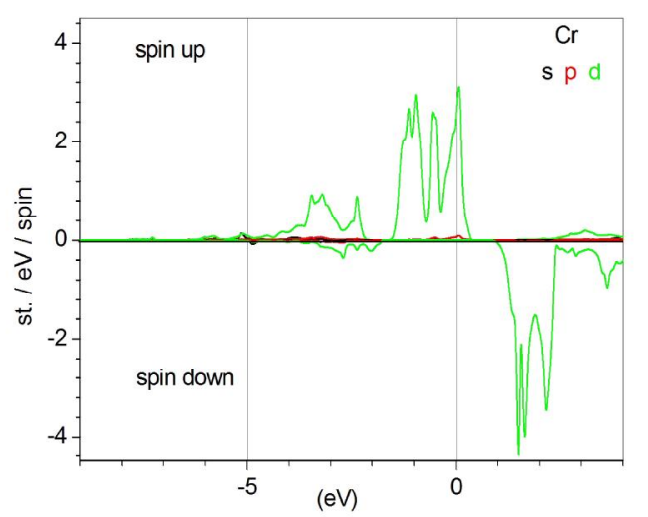

Fig. 4. The partial DOS of Cr in the material $\mathrm{ZnCrSe}$ evaluated with a mixing parameter $\alpha=0$.

Fig. 4 shows that the main contributions at the Fermi level make the $\mathrm{Cr} 3 \mathrm{~d}$ states.

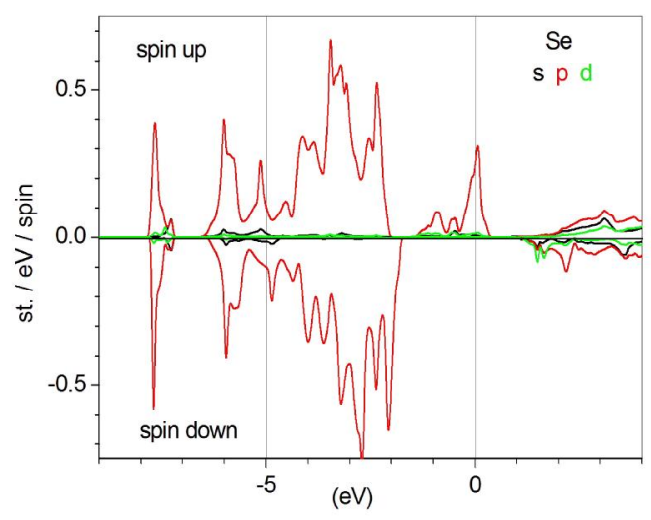

Fig. 5. The partial DOS of Se in the material ZnCrSe evaluated with a mixing parameter $\alpha=0$.

The Se atom also is represented at the Fermi level by its $\mathrm{p}$ states. So, the $\mathrm{Cr}$ and $\mathrm{Se}$ atoms are the main contributors of electrons at the Fermi level.

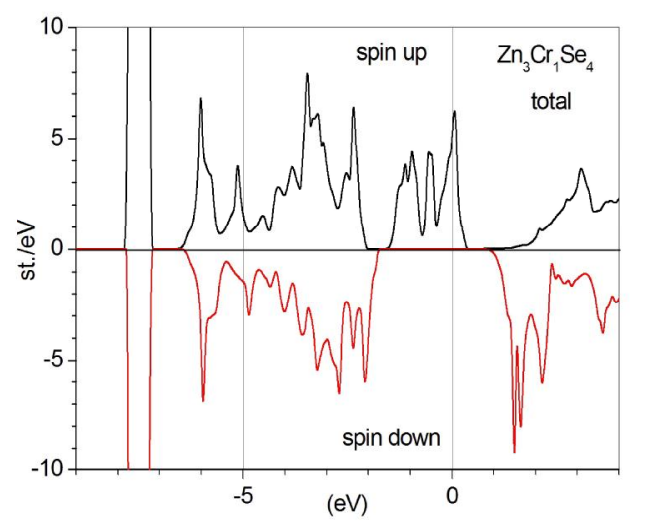

Fig. 6. The total DOS of ZnCrSe material evaluated with a mixing parameter $\alpha=0$. 
The Fig. 6 confirm the half-metallicity of the material under study, when the mixing parameter $\alpha=0$, i.e. the strong correlations of $3 \mathrm{~d}$ electrons are not taken into account.

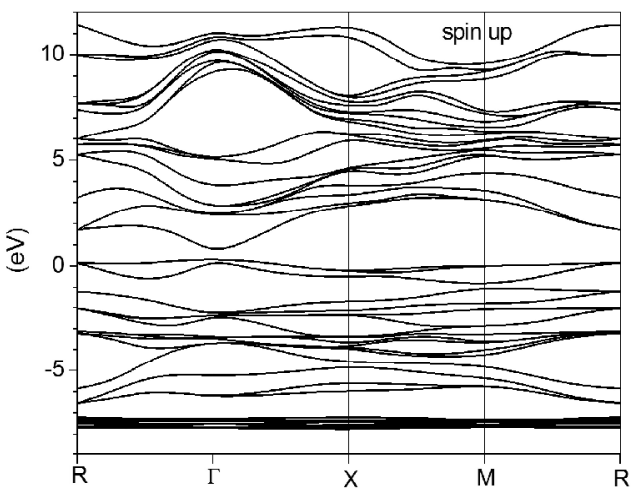

Fig. 7. The electronic energy bands in the $\mathrm{ZnCrSe}$ material obtained with a mixing parameter $\alpha=0.25$.

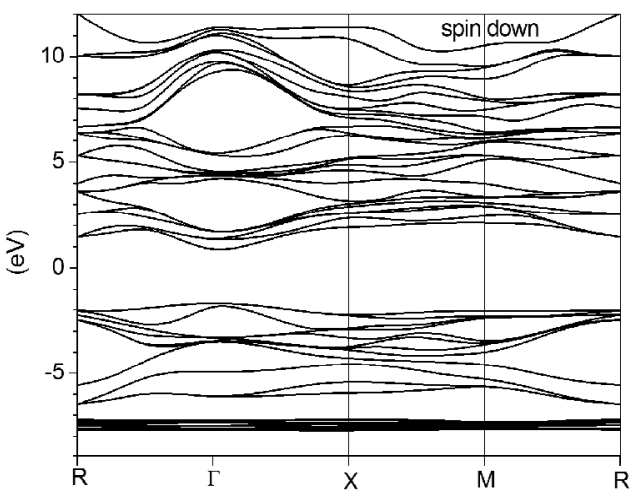

Fig. 8. The electronic energy bands in the $\mathrm{ZnCrSe}$ material obtained with a mixing parameter $\alpha=0.25$.

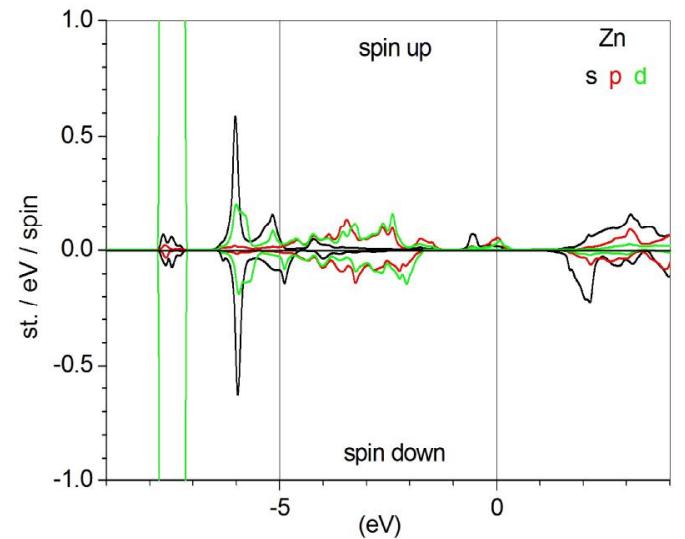

Fig. 9. The partial DOS of Zn in the material ZnCrSe evaluated with a mixing parameter $\alpha=0.25$.

The dispersion curves in Fig. 7 are obtained taking into account the SIE. They show the metallic properties of the material for electrons with spin up. In contrast, the Fermi level in Fig. 8 is located inside the forbidden gap, confirming the semiconductor nature of the $\mathrm{ZnCrSe}$ material for electrons with spin down.

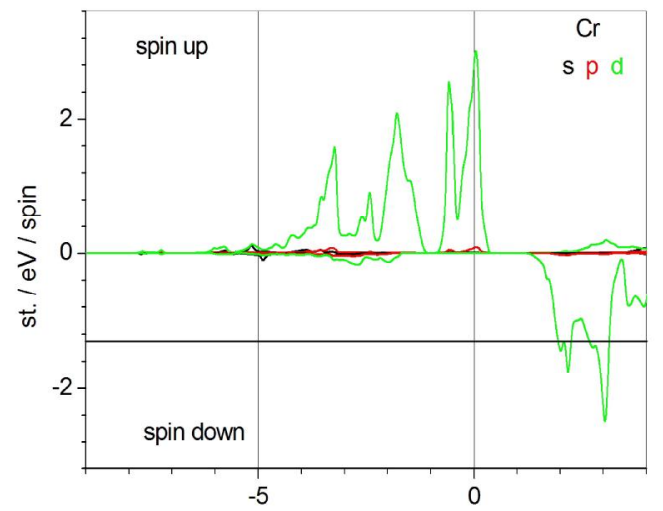

Fig. 10. The partial DOS of Cr in the material $\mathrm{ZnCrSe}$ evaluated with a mixing parameter $\alpha=0.25$.

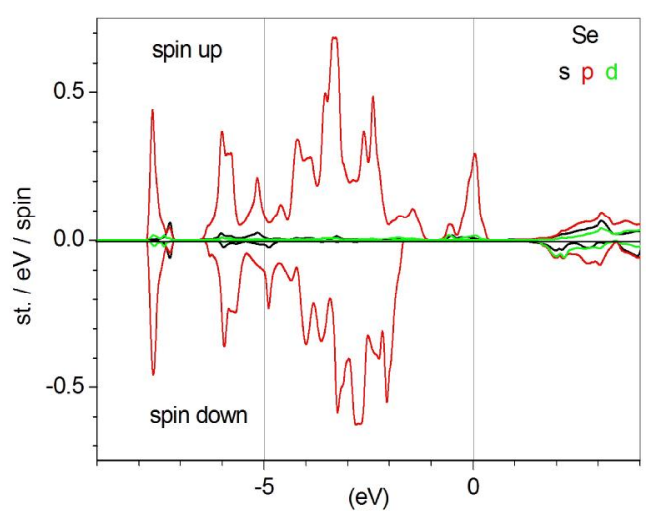

Fig. 11. The partial DOS of Se in the material ZnCrSe evaluated with a mixing parameter $\alpha=0.25$.

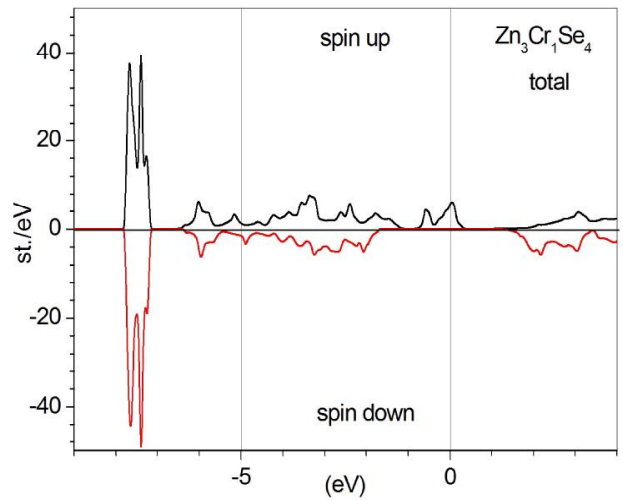

Fig. 12. The total DOS in the material ZnCrSe evaluated with a mixing parameter $\alpha=0.25$.

The Fig. 9 shows that the $\mathrm{Zn}$ atoms contribute very ltlle to the electronic DOS at the Fermi level. The main contribution to DOS at Fermi level provide the $\mathrm{Cr}$ atom, as can be seen from Fig. 10. The contribution of Se atoms to DOS (Fig. 11) at the Fermi level is quite significant, although smaller compared to $\mathrm{Cr}$ atoms. 
Summing up, based on the tota DOS shown in Fig. 12, we conclude that for electrons with spin up the material $\mathrm{ZnCrSe}$ is a metal, and for spin down it exhibits the properties of a semiconductor.

Such compounds are called semi-metals or halfmetals. In particular, these are Heusler alloys, whose intensive research has been conducted over the past decade [10, 11].

\section{Conclusion}

The structural optimization of the material $\mathrm{ZnCrSe}$ confirms its mechanical stability. The electronic structure of the compond, obtained by substitution $\mathrm{Cr} \rightarrow \mathrm{Zn}$, is completely rebuilt, as compared with the crystal ZnSe. In particular, for the spin up the DOS diagrams show the high contribution of the $3 \mathrm{~d} \mathrm{Cr}$ electrons. This would encourage the study of optical properties of this material.

\section{References}

[1] H. Zaari, M. Boujnah, A. El Hachimi, A. Benyoussef, and A. El Kenz, "Optical properties of ZnTe doped with transition metals ( $\mathrm{Ti}, \mathrm{Cr}$ and $\mathrm{Mn}$ )", Optical and Quantum Electronics, vol. 46, no. 1, pp. 75-86, 2014.

[2] R. Yu. Petrus, H. A. Ilchuk, V. M. Sklyarchuk, A. I. Kashuba, I. V. Semkiv, and E. O. Zmiiovska, "Transformation of Band Energy Structure of Solid Solutions CdMnTe", J. Nano-Electron. Phys., vol. 10, no. 6, pp. 06042(5), 2018.

[3] S. V. Syrotyuk and O.P. Malyk, "Effect of Strong Correlations on the Spin-polarized Electronic Energy Bands of the CdMnTe Solid Solution", J. Nano-Electron. Phys., vol. 11, no. 1, pp. 01009(6), 2019.

[4] P. E. Blöchl, "Projector augmented-wave method", Phys. Rev. B, vol. 50, no. 24, pp. 17953-17979, 1994.

[5] F. Tran, P. Blaha, K. Schwarz, and P. Novak, "Hybrid exchange-correlation energy functionals for strongly correlated electrons: Applications to transition-metal monoxides", Phys. Rev. B, vol. 74, pp. 155108(10), 2006.

[6] J. P. Perdew, K. Burke, and M. Ernzerhof, "Generalized Gradient Approximation Made Simple", Phys. Rev. Letters, vol. 77, pp. 38653868, 1996.

[7] S. V. Syrotyuk, Yu. M. Khoverko, N. O. Shcherban, and A. A. Druzhinin, "Effect of the strong electron correlation on the spin-resolved electronic structure of the doped crystals $\mathrm{Si}<\mathrm{B}, \mathrm{Fe}\rangle, \mathrm{Si}<\mathrm{B}, \mathrm{Co}>$ and $\mathrm{Si}<\mathrm{B}, \mathrm{Ni}>$ ", Molecular Crystals and Liquid Crystals, vol. 700, no. 1, pp. 1-12, 2020.

[8] S. Babaie-Kafaki and Z. Aminifard, "Twoparameter scaled memoryless BFGS methods with a nonmonotone choice for the initial step length", Numer. Algorithms, vol. 82, no. 4, pp. 1345-1357, 2019.

[9] X. Gonze, F. Jollet, F. Abreu Araujo, D. Adams, et al., "Recent developments in the ABINIT software package", Comput. Phys. Comm., vol. 205, pp. 106-131, 2016.

[10] T. Graf, C. Felser and S. S. P. Parkin, "Simple rules for the understanding of Heusler compounds", Prog. Solid State Chem., vol. 39, no. 1, pp. 1-50, 2011.

[11] K. Elphick, et al., "Heusler alloys for spintronic devices: review on recent development and future perspectives", Sci. Technol Adv. Mater, vol. 22, no. 1, pp. 235-271, 2021.

\section{СПІН-ПОЛЯРИЗОВАНІ ЕЛЕКТРОННІ ТА МАГНІТНІ ВЛАСТИВОСТІ СЕЛЕНІДУ ЦИНКУ, СИЛЬНО ЛЕГОВАНОГО ХРОМОМ}

\author{
Степан Сиротюк
}

На першому етапі методом оптимізації було визначено структуру кристала ZnSe, легованого атомами хрому ( $\mathrm{ZnCrSe}$ ). На другому етапі електронні властивості цього матеріалу були оцінені у межах двох підходів. Обміннокореляційні функціонали, введені в розрахунки, грунтуються на узагальненому градієнтному наближенні (GGA) та гібридному функціоналі PBE0. Підхід GGA забезпечує металевий стан для електронів зі спіном вгору, а для протилежної орієнтації спіна матеріал $\mathrm{ZnCrSe} \epsilon$ напівпровідником із шириною забороненої зони 2,48 еВ. Гібридний функціонал РВЕ0 також приводить до безщілинного стану для електронних станів зі спіном вгору, а для спінів униз значення ширини забороненої зони дорівнює 2,39 еВ. Магнітний момент елементарної комірки, знайдений 3 двома функціоналами, однаковий і дорівнює $4 \mu_{B}$ (магнетони Бора). Отже, розрахунки $з$ двома обмінно-кореляційними функціоналами передбачають напівметалеві властивості матеріалу $\mathrm{ZnCrSe}$, що робить його цікавим кандидатом для застосувань у спінтроніці.

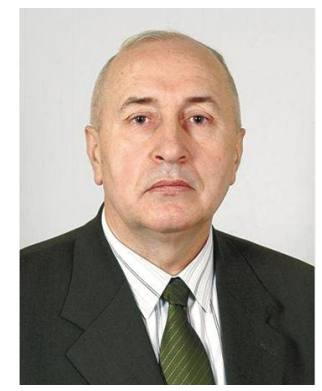

Stepan Syrotyuk - Semiconductor Electronics Department, Lviv Polytechnic National University, Associated Professor. Alma mater: Ivan Franko National University, Physical Faculty. A member of Ukrainian Physical Society. 61 publications in Scopus. electronic, magnetic, optical and elastic properties of crystals, doped with transition elements.

Received: 11.02.2021. Accepted: 25.04.2021 